\title{
Histological aspects of mini-grafting of passiflora edulis sims. And passiflora mucronata lam.
}

\author{
Edilson Romais Schmildt ${ }^{1}$, Layane Segantini Oliari ${ }^{2}$, Rodrigo Sobreira Alexandre ${ }^{3}$, \\ Fábio Oseias dos Reis da Silva ${ }^{4}, \mathrm{Omar}_{\mathrm{Schmildt}}{ }^{4}$
}

\begin{abstract}
In Brazil, the main cultivated passion fruit species is Passiflora edulis, which is affected by Fusarium soil fungus. P. mucronata species stands out because it presents resistance to this fungus, being thus an alternative rootstock to yellow passion fruit. Therefore, the aim of this study was to evaluate the anatomy of mini-grafting by top cleft grafting and simple English type grafting, using shoot tips of adult $P$. edulis plants in clonal rootstocks of $P$. mucronata. When the rootstocks reached approximately $2.5 \mathrm{~mm}$ in diameter and $20 \mathrm{~cm}$ in height, grafting was carried out with Parafilm ${ }^{\circledR}$ tape fasteners and silicone clip. At the end of 60 days, histological analysis of the grafting region was performed to verify the formation of the scarring parenchyma tissue (callus). The filling of the mini-grafting cleft by callus was verified; however, there was no differentiation of the new vascular tissue at 60 days after grafting. During the performance of the simple English type grafting using Parafilm ${ }^{\circledR}$ tape, it was extremely difficult to encircle the tape and at the same time to join the bionts so that tissue junction is perfect. Mini-grafting by top cleft grafting using Parafilm ${ }^{\circledR}$ tape fastener is recommended.
\end{abstract}

Index terms: Passiflora spp., anatomy, calogenesis, grafting.

Corresponding author: e.romais.s@gmail.com Received: Janeiro 24, 2017. Accepted : February, 142017.

Copyright: All the contents of this journal, except where otherwise noted, is licensed under a Creative Commons Attribution License.

\section{(cc) $\mathrm{EY}$}

\section{Aspectos histológicos da minienxertia de \\ Passiflora edulis sims. e Passiflora mucronata lam.}

Resumo- No Brasil, a principal espécie cultivada de maracujazeiro é Passiflora edulis (maracujazeiro-azedo), a qual é acometida pelo fungo de solo Fusarium. A espécie P. mucronata destaca-se por apresentar resistência a este fungo, sendo assim uma alternativa como portaenxerto ao maracujazeiro-amarelo. Portanto, objetivou-se avaliar a anatomia da minienxertia por garfagem no topo em fenda cheia e inglês simples, utilizando ápices caulinares de plantas adultas de $P$. edulis em portaenxertos clonais de $P$. mucronata. Quando os porta-enxertos atingiram aproximadamente 2,5 $\mathrm{mm}$ de diâmetro do coleto e $20 \mathrm{~cm}$ de altura, procedeu-se a enxertia com os fixadores fita Parafilm ${ }^{\circledR}$ e clipe de silicone. Ao completar 60 dias, foi realizada a análise histológica da região de enxertia para verificação da formação do tecido parenquimático cicatricial (calo). Verificou-se o preenchimento da fenda de minienxertia por calo; no entanto, não houve diferenciação do novo tecido vascular, aos 60 dias após a minigarfagem. Durante a execução da minienxertia inglês simples com uso de fita Parafilm ${ }^{\circledR}$, percebeu-se extrema dificuldade em circundar a fita e, ao mesmo momento, unir os biontes, de forma que fique perfeita a junção dos tecidos. Recomenda-se a minienxertia no topo em fenda cheia com o uso do fixador fita Parafilm ${ }^{\circledR}$.

Termos para indexação: Passiflora spp., anatomia, calogênese, enxertia. 
The genus Passiflora belonging to the Passifloraceae family has approximately 520 species of which 140 are native to Brazil (CERVI, 2005; 2006). Some of these species have economic importance due to the quality of fruits for consumption or because they present pharmaceutical and cosmetic properties (CROCHEMORE et al., 2003).

In Brazil, the main cultivated passion fruit species is Passilfora edulis Sims. followed by Passiflora alata Curtis., being the world's largest passion fruit producer, with a cultivated area of 57,277 ha and production of 838,244 t (IBGE, 2013).

Commercial passion fruit $P$. edulis is susceptible to Fusarium oxysporum f. sp. passiflorae, causing fusarium wilt and Fusarium solani, causing stem rot. According to Ortiz et al. (2014), these diseases cause in P. edulis hypertrophy and hyperplasia of the cambium, xylem and phloem; destruction of xylem fibers and amyloplasts in parenchymal cells, as well as the production of gels, causing an expressive reduction in crop productivity. However, there are differences in the colonization mechanism: F. solani is mainly concentrated in the stem area, while $F$. oxysporum penetrates the roots and moves through the vascular system to colonize the plant. As preventive measure, Passiflora mucronata Lam. stands out due to its resistance to fungi $F$. oxysporum $\mathrm{f}$. sp. passiflorae (PREISIGKE et al., 2015) and F. solani (FREITAS et al., 2016), which can be used as rootstock for commercial species $P$. edulis and $P$. alata.

Commercial passion fruit species are propagated through seeds; however, in search of solving plant health problems, researchers study the grafting of commercial species using rootstocks of wild species with some degree of resistance to certain soil diseases. Thus, Alexandre et al. (2013) proposed the mini-grafting method of $P$. edulis/P. mucronata, in which the establishment was $80 \%$ was observed. Oliari et al. (2016), in a study on the mini-grafting of $P$. edulis on $P$. mucronata obtained $89 \%$ of live seedlings at 21 days after grafting (DAG). Cavichioli et al. (2011) verified the survival of $91 \%$ of $P$. edulis/Passiflora gibertti N. E. Brown seedlings grown in an area infected with Fusarium solani and nematode Rotylenchulus reniformis.

The histological study allows the visualization and better understanding of the healing process. Pina et al. (2012) visualized callus formation from parenchyma cells and cambial region five days after mini-grafting on Prunus armeniaca L./Prunus cerasifera Ehrhart. Nogueira Filho et al. (2010a) observed that all the space of the grafting cleft (P. edulis/P. edulis and P. alata) was filled by scarring parenchyma tissue at nine DAG. Ribeiro et al. (2015) observed the formation of callus from the proliferation of parenchyma cells of the rootstock cortex three days after mini-grafting (DAM) in hypocotyls of $P$. edulis. At seven DAM, the cells produced at the base of the bud (graft) promote the union with the rootstock callus. At $10 \mathrm{DAM}$, there is a differentiation in procambium and parenchymatic tissues from the callus. At 15 DAM, these parenchyma cells originate procambular tissues and initiate the differentiation of tracheal elements and the epidermis. Vascular connections are established at 20 DAM, promoting the accelerated development of the graft in which the bud development occurs at 30 DAM.

To confirm the success of grafting as a vegetative propagation method, Salazar et al. (2015) carried out studies on the physical and chemical characterization of P. edulis fruits on P. edulis, P. gibertii and P. mucronata. These authors verified that the fruits are in agreement with the standard of passion fruit commercialization (HORTIBRASIL, 2015) for soluble solids content, titratable acidity, bark and juice coloration and vitamin C content. Salazar et al. (2016) quantified $\beta$-carotene and ascorbic acid in the juice from ungrafted and grafted fruits (P. edulis/P. mucronata) and verified that there was no statistical difference for $\beta$-carotene.

In this work, performed in CEUNES, the anatomy of mini-grafting by top cleft grafting and simple English type grafting was analyzed, using stem apexes of adult $P$. edulis plants on clonal P. mucronata grafts.

Adult $P$. mucronata plant branches were collected at "Fazenda Cedro", in the municipality of São Mateus, ES, in July 2015. Individual stakes were then sectioned in a single bevel and were immersed in indole-3-butyric acid (IBA) at concentration of $1000 \mathrm{mg} \mathrm{kg}^{-1}$ (ALEXANDRE et al., 2014), stacked in tubes containing Bioplant ${ }^{\mathbb{R}}$ substrate (Table 1) for rooting and formation of clonal rootstocks. The chemical and physical analysis of substrates was carried out at the Laboratory of Soil, Leaf and Water Analysis (LAGRO) of CEUNES/UFES, where the determination of dry density and porosity (BRASIL, 2007) was carried out. Particle size (Table 1) was determined by dry sieving, sieving $100 \mathrm{~g}$ of each substrate dried in the air, which was coupled in a set of sieves with mesh $>4.75 ; 2.00$ to $4.75 ; 1.00$ to $2.00 ; 0.5$ to $1.00 ; 0.25$ to 0.5 and $<0.25 \mathrm{~mm}$, shaking for 5 minutes. The fractions retained in each sieve were weighed and the percentages were calculated on the total weight of samples. After two months, seedlings were transferred to black plastic bags $(9 \times 15 \mathrm{~cm})$ added of Bioplant ${ }^{\mathbb{B}}$ substrate for better root development. Cuttings were kept in a greenhouse, located at the Experimental Farm of the Federal University of Espírito Santo (UFES) in São Mateus, ES; on the following geographical coordinates $18^{\circ} 43$ " $\mathrm{S} ; 30^{\circ} 51$ "W and $39 \mathrm{~m}$ above sea level, with controlled irrigation for six months. During the first month, period of rooting induction, sprinkler irrigation was performed for four minutes every two hours, from 7:00 am to $11: 00 \mathrm{pm}$. After this period, irrigation was two minutes every hour, from 7:00 am to $11: 00 \mathrm{pm}$. 
Table 1 - Chemical and physical characteristics of Bioplant ${ }^{\circledR}$ commercial substrate used in the production of $P$. mucronata clonal rootstocks

\begin{tabular}{|c|c|c|c|}
\hline Chemical characteristic & Values & Physical characteristics & Values \\
\hline Total organic matter $\left(\right.$ dag $\left.\mathrm{kg}^{-1}\right)$ & 8.5 & Dry or wet density $\left(\mathrm{kg} \mathrm{m}^{-3}\right)$ & 303.59 \\
\hline $\mathrm{pH}$ in $\mathrm{H}_{2} \mathrm{O}$ & 5.2 & Total porosity $(\%)$ & 64.09 \\
\hline P Mellich $\left(\mathrm{mg} \mathrm{dm}^{-3}\right)$ & 198.0 & Particle size (mm) & $\begin{array}{c}\text { Particle size distribution } \\
(\%)\end{array}$ \\
\hline $\mathrm{Na}^{+}\left(\mathrm{mg} \mathrm{dm}{ }^{-3}\right)$ & 510.0 & $>4.75$ & 0.07 \\
\hline exchangeable $\mathrm{K}^{+}\left(\mathrm{mg} \mathrm{dm}^{-3}\right)$ & 990.0 & 2.00 to 4.75 & 34.56 \\
\hline exchangeable $\mathrm{Mg}^{2+}(\mathrm{cmol})$ & 3.2 & 1.00 to 2.00 & 43.36 \\
\hline exchangeable $\mathrm{Ca}^{2+}(\mathrm{cmol})$ & 7.8 & 0.5 to 1.00 & 18.78 \\
\hline exchangeable $\mathrm{Ca}^{2+}+\mathrm{Mg}^{2+}\left(\mathrm{mmol}_{\mathrm{c}} \mathrm{dm}^{-3}\right)$ & 11.0 & 0.25 to 0.5 & 2.31 \\
\hline $\mathrm{Al}^{3+}(\mathrm{cmol})$ & 0.4 & $<0.25$ & 0.92 \\
\hline $\mathrm{H}^{+}+\mathrm{Al}^{3+}(\mathrm{cmol})$ & 4.7 & & \\
\hline $\mathrm{Zn}\left(\mathrm{mg} \mathrm{dm} \mathrm{m}^{-3}\right)$ & 15.2 & & \\
\hline $\mathrm{Fe}\left(\mathrm{mg} \mathrm{dm}^{-3}\right)$ & 206.0 & & \\
\hline $\operatorname{Mn}\left(\mathrm{mg} \mathrm{dm}^{-3}\right)$ & 45.0 & & \\
\hline $\mathrm{Cu}\left(\mathrm{mg} \mathrm{dm}{ }^{-3}\right)$ & 2.4 & & \\
\hline $\mathrm{B}\left(\mathrm{mg} \mathrm{dm} \mathrm{m}^{-3}\right)$ & 1.22 & & \\
\hline CTC (t) (cmol) & 13.9 & & \\
\hline Base Saturation (\%) & 74.2 & & \\
\hline
\end{tabular}

When $P$. mucronata rootstocks reached approximately $2.5 \mathrm{~mm}$ in diameter and $20 \mathrm{~cm}$ in height, shoot tips (end of each branch) were collected from adult $P$. edulis plants cv. FB 200, $5 \mathrm{~cm}$ long, approximately 2 to $2.5 \mathrm{~mm}$ in diameter, in a commercial crop of one and a half years free of diseases and pests located in the municipality of São Mateus, ES. These apexes were conditioned in thermal boxes and sprayed with water in order to avoid losing turgescence, and immediately sent to the Laboratory of Plant Improvement for the execution of mini-grafting modified by Alexandre et al. (2013), with the use of top cleft grafting and simple English type grafting.

With the aid of steel blades, a double bevel cut was performed at the base of the graft (shoot tips) of adult $P$. edulis plants, which was introduced into the rootstock cleft, approximately one centimeter long. For the rootstock $x$ graft, circular silicone clips and Parafilm $\mathrm{M}^{\circledR}$ tape, $1 \mathrm{~cm}$ wide and $3 \mathrm{~cm}$ long, were used, which shows high permeability to $\mathrm{O}_{2}$ and $\mathrm{CO}_{2}$. Subsequently, the entire grafts and part of the rootstock, just below the grafted region, were packed in plastic bag $(7 \times 15 \mathrm{~cm})$ to constitute a humid chamber and reduce dehydration of the grafted region. This plastic bag was removed 10 days after mini-grafting was performed during the entire experiment in greenhouse, covered with $150 \mu \mathrm{m}$ plastic film, front and side of anhyphidic screen and micro sprinkler type irrigation with six irrigations daily with intervals of three hours, and wetting period of three minutes. Under these conditions, humidity remains around $60 \%$.

The histological analysis occurred at 60 days after mini-grafting. Cuts of the region below and above the grafting were performed with steel blade. This material was stored in glass pots with FAA solution (formalin, acetic acid and ethyl alcohol - 1: 1: $1 \mathrm{v} / \mathrm{v}$ ) for 48 hours, which was then replaced by $70 \%$ alcohol according to methodology proposed by Johansen (1940).

Sections were stained with 1\% safranin (KRAUS; ARDUIM, 1997), removing the excess with water and the slides and coverslips were assembled with glycerine. The detailed cross-sections were visualized by Motic ${ }^{\circledR}$ BA 210 photomicroscope coupled to Moticam 3MP camera and the longitudinal and transverse sections using Leica EZ4HD Lens.

The analysis of sections in longitudinal view allowed verifying that, at 60 days after mini-grafting (DAM), the silicone clip and Parafilm ${ }^{\circledR}$ tape fasteners used to promote the physical contact between graft ( $P$. edulis) and rootstock ( $P$. mucronata) assisted in the junction of tissues (Figure 1B, D and F). The spaces of the mini-grafting cleft were filled by the multiplication of parenchyma cells in a process called calogenesis. However, efficiency was not observed in the full extent of the mini-grafting cleft. The explanation for this may be related to the morphological aspects of stems, such as the pentagonal shape in $P$. edulis and circular shape in $P$. mucronata and the time of contact between graft and rootstock of 60 days, requiring more than this time for complete filling. Oliari et al. (2016) observed that the use of a circular V-shape clip, and Parafilm ${ }^{\circledR}$ tape fastener aided the attachment of the graft $(P$. edulis $)$ and the rootstock $(P$. mucronata) at 21 DAM, and that cell multiplication did not fully occur in the graft cleft, requiring longer time for the cell multiplication to complete the connection between bionts. Complete filling by calogenic cells in the $P$. edulis/ $P$. edulis mini-grafting according to Ribeiro et al. (2015) was seven DAM and the parenchyma callus 
differentiation of 15 DAM.

The union of tissues of the mini-grafting cleft is formed by the division of callus cells, originally from the graft and the rootstock, which then differentiate to form the vascular cambium. Three consecutive steps occur in successful grafting: adhesion between graft and rootstock cells; proliferation of callus cells and vascular differentiation at the grafting interface (HARTMANN et al., 2011). At 60 DAM, it was not possible to visualize the vascular differentiation (Figure 2).

At $60 \mathrm{DAM}$, it is possible to visualize that there was not yet complete calogenesis in the grafting cleft (Figure 2A, C and E); however, the cells that multiplied were sufficient and important to transport water, nutrients and phytohormones to the graft, since they kept alive. The callus cells act as a bridge between graft and rootstock, allowing the movement of water and nutrients, since the vascular tissues were damaged by the cut (PINA et al., 2012).

The new parenchyma cells proliferate from 1 to 7 days in both graft and rootstock. These cells are the first response to grafting (PINA; ERREA, 2005; HARTMANN et al., 2011). In this work, it was possible to verify mitoses only of graft cells (Figure 3A and B). As the graft is composed of stem apexes, its cells are younger (absolute growth rate of $2.5 \mathrm{~cm} \mathrm{day}^{-1}$, in addition to being a tender and very hydrated tissue) and for being meristematic tissue, site of auxin synthesis, they show higher cell division rate. Oliari et al. (2016) also observed, at 21 DAM, mitoses only of graft cells.

According to Hartmann et al. (2011), the graft does not grow successfully if there is no vascular connection, so that it can receive water, nutrients and photoassimilates. According to Nogueira Filho et al. (2010a), due to nonjuxtaposition of tissues in the $P$. edulis/P. edulis grafting region, a sinuous profile of the vascular tissues formed in the sense of touching themselves for connection to occur.
During the execution of the simple English type grafting using Parafilm ${ }^{\circledR}$ tape, it was extremely difficult to encircle the tape and at the same time to join bionts so that the tissue junction is perfect. The seedlings whose mini- grafting was simple English type with the use of silicone clip did not survive. In this same sense, it was also noticeable the difficulty in inserting the clip in the grafting region, because bionts did not perfectly fit and match the size of the clip and incisions made in the graft and rootstock, thus leaving the ends of bionts uncovered, that is, without direct contact with the clip, which explains the low efficiency of this fastener. The opposite was observed with the mini-grafting by top cleft grafting, with greater practicality and efficiency, since after cutting the graft in a double bevel, it perfectly fits in the grafting cleft, making it easier for the operator to place the clip and encircle the Parafilm ${ }^{\circledR}$ tape.

Other fasteners are used in grafting of passion fruit, for example, the crepe-like adhesive tape that resembles Parafilm ${ }^{\circledR}$ tape, used as fastener of the hypocotylated graft in a cleft grafting filled with $P$. edulis in $P$. alata, where after nine DAG the cleft was completely filled by callus (NOGUEIRA FILHO et al., 2010b). Santos et al. (2016) in a study on crepe-like adhesive tape, metallic hair clip and spring graft clamp fasteners in P. edulis hypocotylated graft on $P$. alata, $P$. gibertii and $P$. cincinnata, verified that there was no statistical difference for such fasteners in the analysis of seedling survival, leaf number, stem diameter and graft height at 30,60 and 90 DAG. The authors emphasize the practicality and speed in the use of clamp in relation to tape. Rego et al. (2012) evaluated the hypocotylated grafting in five combinations of $P$. edulis genotypes ('BRS Ouro Vermelho', 'BRS Sol do Cerrado', 'BRS Gigante Amarelo', open pollinator variety and Hortivale cv.) using straws, metal clips, plastic clips and metal and plastic clips as fasteners. The metal clip was inferior to the others in the protection of the grafted region due to the oxidation of the material, but the others provided $100 \%$ seedling survival at 60 DAG. 


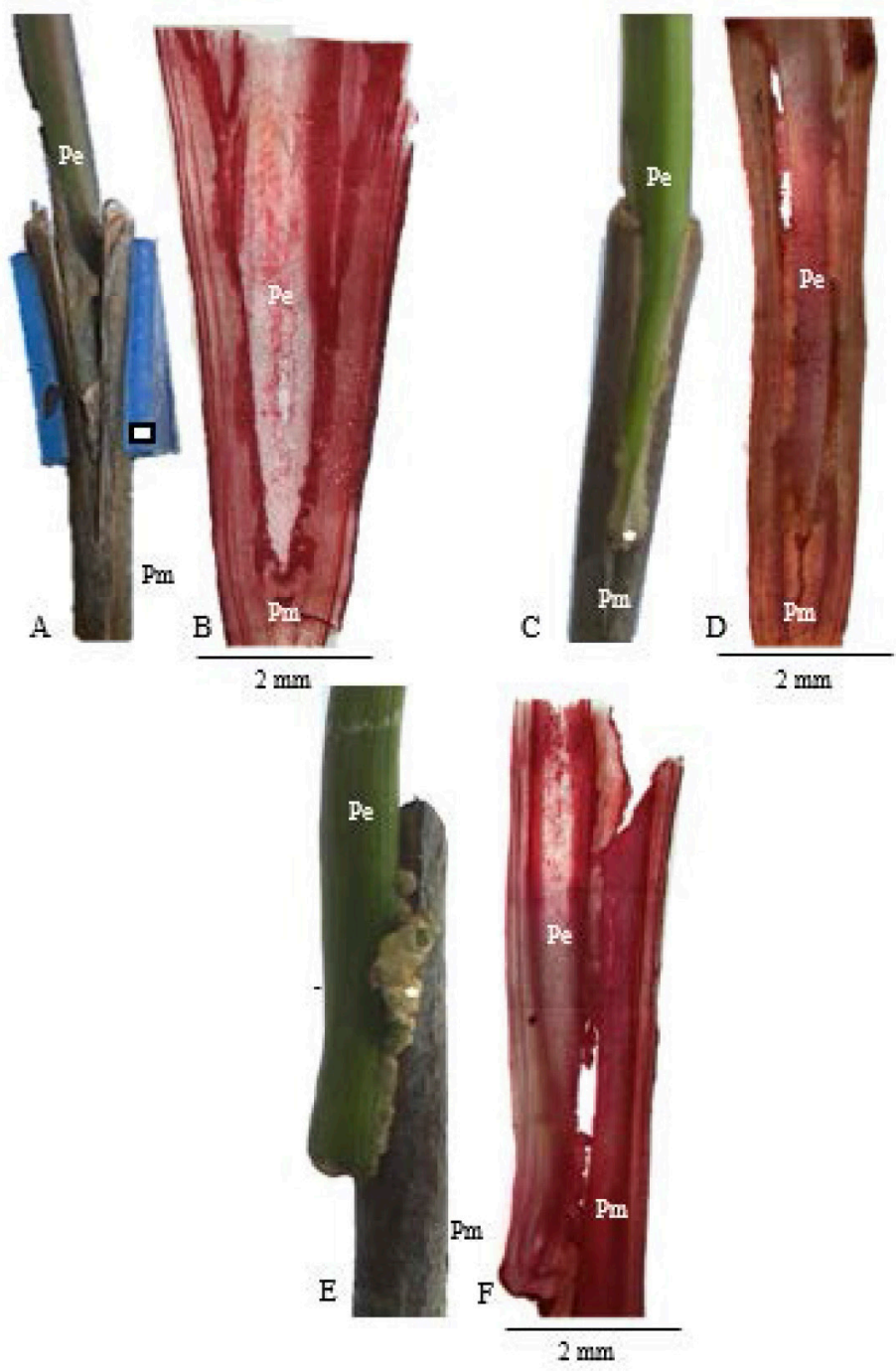

Figure 1 - Mini-grafting of $P$. edulis $(\mathrm{Pe})$ on P. mucronata $(\mathrm{Pm})$ at 60 days. Cleft grafting with use of silicone clip (A) and longitudinal section (B), cleft grafting with Parafilm ${ }^{\circledR}$ tape (C) and longitudinal section (D) and simple english type grafting using Parafilm ${ }^{\circledR}$ tape (E) and longitudinal section (F). Legend - Square: silicone clip and star: cell multiplication. 


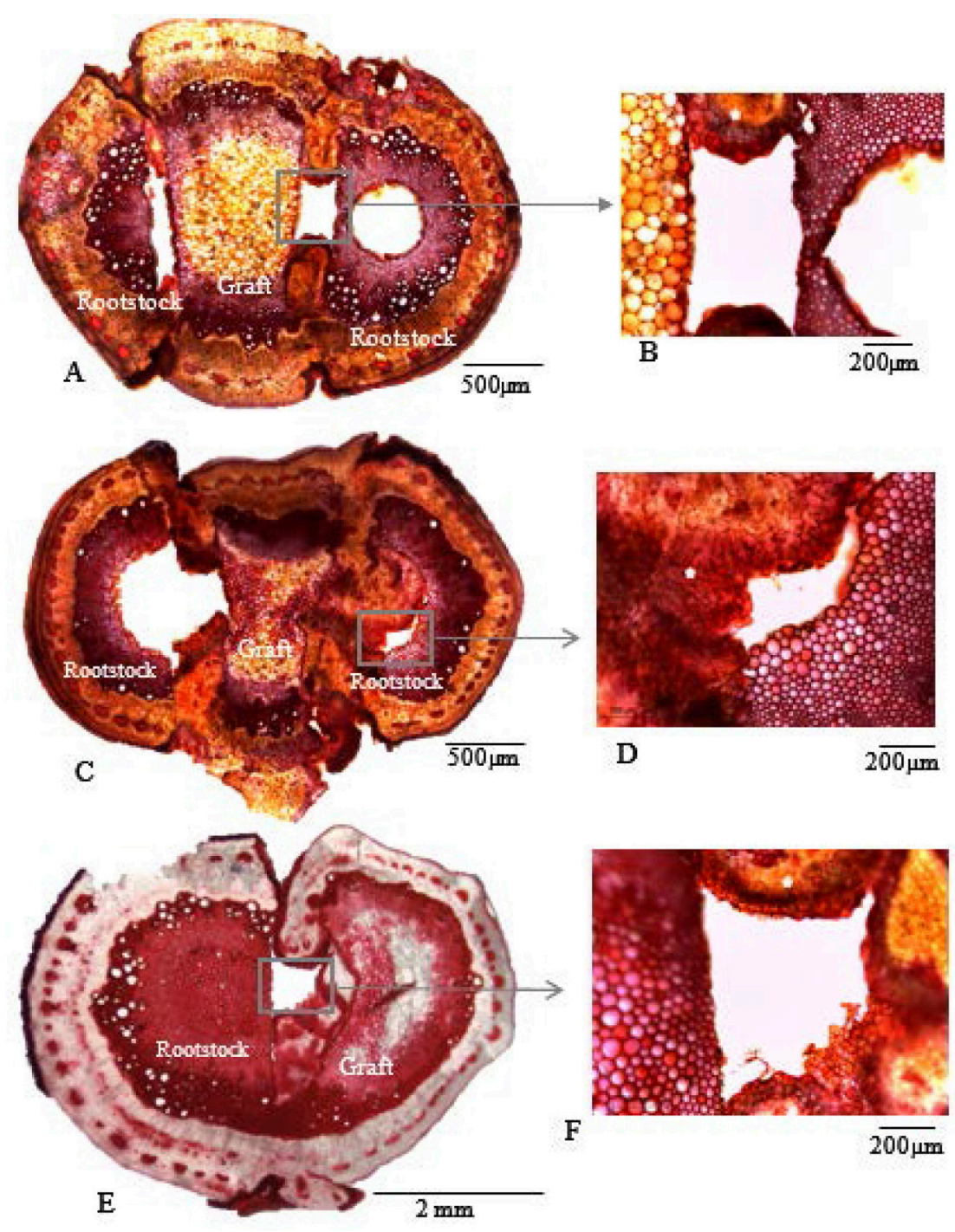

Figure 2 - Cross sections of the grafted region of $P$. edulis on P. mucronata. Cleft grafting with use of silicone clip (A and B). Cleft grafting using Parafilm ${ }^{\circledR}$ tape (C and D). Simple english type grafting using Parafilm ${ }^{\circledR}$ tape (E and F). Star: cell multiplication. 


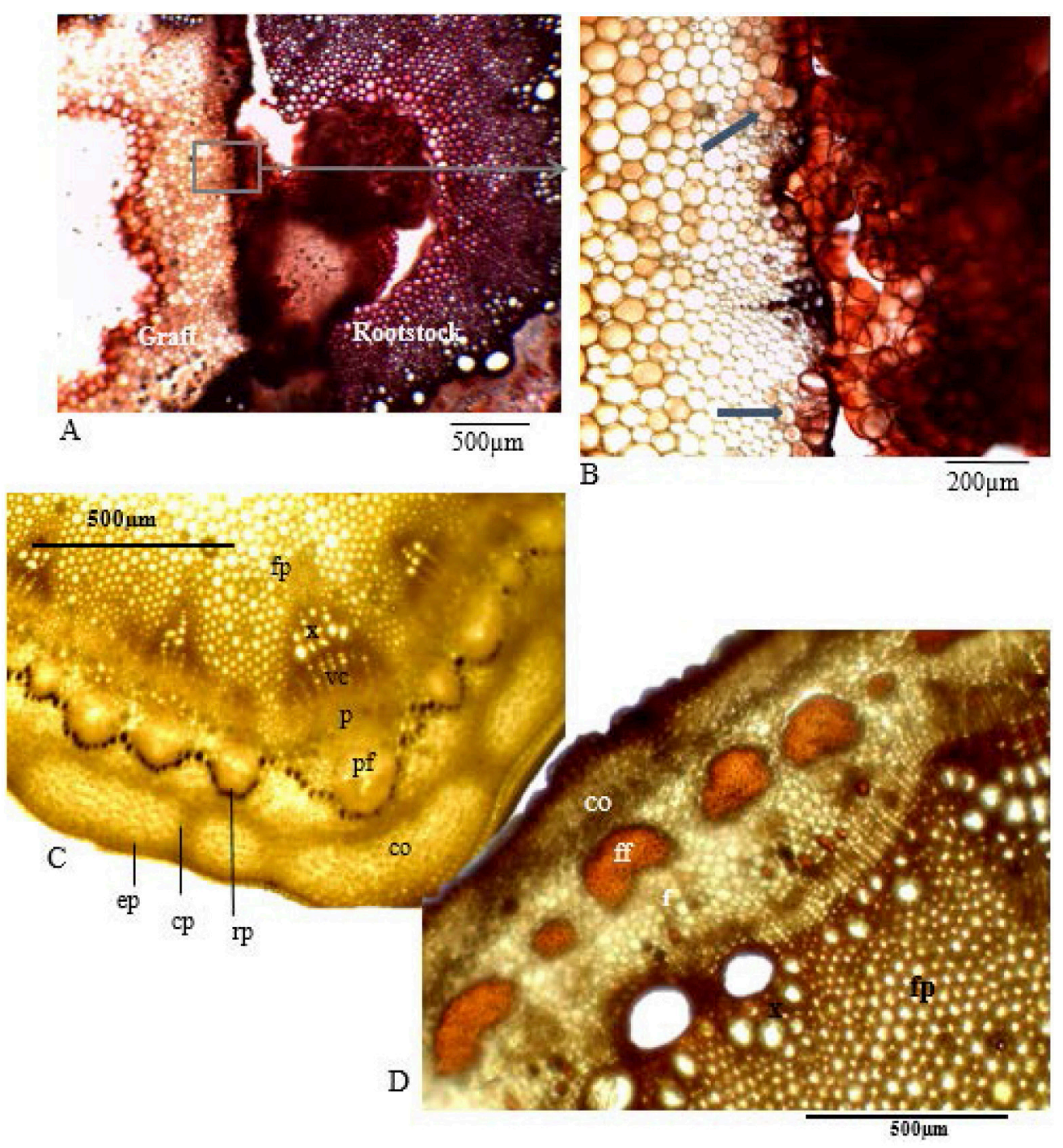

Figure 3 - Cross sections of the grafted region of $P$. edulis on P. mucronata. Detailed overview showing cell multiplication (A and B). Black arrow: mitosis from graft cells. Anatomical section of the stem apex of P. edulis (C). Anatomic section of P. mucronata stem (D). ep: epidermis, cp: chlorophyllic parenchyma, rp: reserve parenchyma, co: colenchyma, pf: phloem fibers, p: phloem, vc: vascular cambium, x: xylem, fp: fundamental parenchyma.

High compatibility between $P$. edulis and $P$. mucronata was observed in the works of Alexandre et al. (2013) and Oliari et al. (2016). The same was observed by Morgado et al. (2015), when grafting P. edulis on P. mucronata, with seedling height values of $74.13 \mathrm{~cm}$ at 75 days after grafting; at the moment of planting seedlings with at least $15 \mathrm{~cm}$ are recommended.

\section{Conclusion}

Therefore, it is concluded that the use of Parafilm ${ }^{\mathbb{R}}$ tape is the most suitable for the mini-grafting modality by top cleft grafting between $P$. edulis and $P$. mucronata and that filling of the graft cleft was performed with graft parenchyma cells (P. edulis).

\section{References}

ALEXANDRE, R.S.; COSTA, P.R.; CHAGAS, K.; MAYRINCK, L.G.; DETONI, J.L.; SCHMILDT, E.R. Enraizamento adventício de estacas de maracujazeiro silvestre Passiflora mucronata Lam.: forma de veiculação e concentrações do ácido indol-3-butírico. Revista Ceres, Viçosa, MG, v.61, n.4, p.567-571, 2014.

ALEXANDRE, R.S.; LOPES, J.C.; TIRADENTES, A.T.; BRUCKNER, C.H.; OTONI, W.C. Metodologia de minienxertia em maracujazeiro. Revista Brasileira de Fruticultura, Jaboticabal, v.35, n.1, p.329-332, 2013. 
BRASIL. Ministério da Agricultura, Pecuária e Abastecimento. Instrução Normativa SDA n ${ }^{\circ} 17$ de 24 de maio de 2007. Métodos analíticos oficiais para análise de substratos para plantas e condicionadores de solo. Diário Oficial da União, Brasília, DF, Seção 1, n.99.

CAVICHIOLI, J.C.; CORRÊA, L. de S.; GARCIA, M.J. de M.; FISCHER, I.H. Desenvolvimento, produtividade e sobrevivência de maracujazeiro-amarelo enxertado e cultivado em área com histórico de morte prematura de plantas. Revista Brasileira de Fruticultura, Jaboticabal, v.33, n.2, p.567-574, 2011.

CERVI, A.C. Espécies de Passiflora L. (Passifloraceae) publicadas e descritas nos últimos 55 anos (1950-2005) na América do Sul e principais publicações brasileiras. Estudos de Biologia, Curitiba, v.27, n.61, p.19-24, 2005.

CERVI, A.C. O gênero Passiflora L. (Passifloraceae) no Brasil, espécies descritas após o ano de 1950. Adumbratones ad Summae Editonem, Madrid, v.16, p.1-5, 2006.

CROCHEMORE, M.L.; MOLINARI, H.B.; STENZEL, N.M.C. Caracterização agromorfológica do maracujazeiro (Passiflora spp.). Revista Brasileira de Fruticultura, Jaboticabal, v.25, n.1, p.5-10, 2003.

FREITAS, J.C.O.; VIANA, A.P.; SANTOS, E.A.; PAIVA, C.L.; SILVA, F.H.L.; AMARAL JÚNIOR, T.; SOUZA, M.M.; DIAS, V.M. Resistance to Fusarium solani and characterization of hybrids from the cross between P.mucronata and P.edulis. Euphytica, Dordrecht, v.28, n.3, p.493-507, 2016.

HARTMANN, H.T.; KESTER, D.E.; DAVIES JUNIOR, F.T.; GENEVER, R.L. Plant propagation: principles and practices. $8^{\text {th }}$ ed. New Jersey: Prentice-Hall, 2011. p.915.

HORTIBRASIL. Programa Brasileiro para Modernização da Agricultura. Maracujá-azedo: cartilha para classificação. Disponível em: http://www.hortibrasil. org.br/images/stories/folders/maracuja.pdf. Acesso em: 21 abr. 2018.

IBGE - Instituto Brasileiro de Geografia e Estatística. Produção agrícola municipal. Rio de Janeiro, 2016. Disponível em: $<$ www.ibge.gov.br $>$. Acesso em: 29 jul. 2016.

JOHANSEN, D.A. Plant microtechniche. New York: McGraw Hill Book, 1940. p.523.
KRAUS, J.E.; ARDUIM, M. Manual básico de métodos em morfologia vegetal. Seropédica: EDUR, 1997. p.194.

MORGADO, M.A.D.; BRUCKNER, C.H.; ROSADO, L.D.S.SANTOS, C.E.M. dos. Desenvolvimento de mudas de maracujazeiro-azedo enxertadas em espécies silvestres de Passiflora. Revista Brasileira de Fruticultura, Jaboticabal, v.37, n.2, p.471-479, 2015.

NOGUEIRA FILHO, G.C.; RONCATTO, G.; RUGGIERO, C.; OLIVEIRA, J.C. de; MALHEIROS, E.B.; DAMIÃO FILHO, C.F. Aspectos histológicos da união da enxertia hipocotiledonar do maracujazeiroamarelo. Revista Brasileira de Fruticultura, Jaboticabal, v.32, n.2, p.515-521, 2010 b.

NOGUEIRAFILHO, G.C.; RONCATTO, G.; RUGGIERO, C.; OLIVEIRA, J.C.de; MALHEIROS, E.B. Estudo da enxertia hipocotiledonar do maracujazeiro-amarelo sobre dois porta-enxertos, através de microscopia eletrônica de varredura. Revista Brasileira de Fruticultura, Jaboticabal, v.32, n.2, p.647-652, 2010a.

OLIARI，L.S.; GILES, J.A.D.; MAYRINCK, L.G.; OLIVEIRA, J.P.B.; LOPES, J.C.; OTONI, W.C.; SCHMILDT, E.R.; AOYAMA, E.M.;ALEXANDRE, R.S. Mini-grafting of adult Passiflora edulis Sims f. flavicarpa Deg. scions onto vegetatively propagated adult rootstocks of P.mucronata Lam. Australian Journal of Crop Science, Lismore, v.10, p.490-496, 2016.

ORTIZ，E.; CRUZ，M.; MELGAREJO，L.M.; MARQUÍNEZ, X.; HOYOS-CARVAJAL, L. Histopathological features of infections caused by Fusarium oxysporum and $F$. solani in purple passionfruit plants (Passiflora edulis Sims). Summa Phytopathologica, Botucatu, v.40, n.2, p.134-140, 2014.

PINA, A.; ERREA, P.; MARTENS, H.J. Graft union formation and cell-to-cell communication via plasmodesmata in compatible and incompatible stem unions of Prunus spp. Scientia Horticulturae, Amsterdam, v.143, p.144-150, 2012

PINA, A.; ERREA, P.A review of new advances in mechanism of graft compatibility-incompatibility. Scientia Horticulturae, Amsterdam, v.106, p.1-11, 2005.

PREISIGKE, S. da C.; NEVES, L. G.; ARAÚJO, K. L.; BARBOSA, N.R.; SERAFIM, M. E.; KRAUSE, W. Multivariate analysis for the detection of Passiflora species resistant to colar rot. Bioscience Journal, Uberlândia, v.31, n.6, p.1700-1707, 2015. 
REGO, M.M.; BRITO, S.G.; REGO, E.R.; COSTA, F.R.; FORTUNATO, F.L.G. Hypocotyledonary grafting in passion fruit (Passiflora edulis Sims). Acta Horticulturae, Belgium, v.928, p.139-144, 2012.

RIBEIRO, L.M.; NERY, L.A.; VIEIRA, L.M.; SIMÕES, M.O.M. Histological study of micrografting in passionfruit. Plant Cell Tissue and Organ Culture, Heidelberg, v. 123, p.173-181, 2015.

SALAZAR, A.H.; SILVA, D.F.P.da; BRUCKNER, C.H. Effect of two wild rootstocks of genus Passiflora L. on the contente of antioxidants and fruit quality of yellow passion fruit. Bragantia, Campinas, v.75, n.2, p.164-172, 2016.

SALAZAR, A.H.; SILVA, D.F.P.da; SEDIYAMA, C.S.; BRUCKNER, C.H. Caracterização física e química de frutos de maracujazeiro-amarelo enxertado em espécies silvestres do gênero Passiflora cultivado em ambiente protegido. Revista Brasileira de Fruticultura, Jaboticabal, v.37, n.3, p.635-643, 2015.

SANTOS, C.H.B.; CRUZ NETO, A.J. da; SOARES, T.L.; OLIVEIRA, E.J. de; JESUS, O.N. de; GIRARDI, E.A. Porta-enxertos e fixadores de enxerto para enxertia hipocotiledonar de maracujazeiro azedo. Ciência Rural, Santa Maria, v.46, n.1, p.30-35, 2016. 